\title{
New Names and Combinations in the Genera Bacteroides Castellani and Chalmers, Fusobacterium Knorr, Eubacterium P'́revot, Propionibacterium Delwich, and Lactobacillus Orla-Jensen
}

\author{
W. E. C. MOORE AND LILLIAN V. HOLDEMAN
}

Anaerobe Laboratory, Division of Basic Science, College of Agriculture, Virginia Polytechnic Institute and State University, Blacksburg, Virginia

Volume 23, no. 1, p. 69, title: Change title to read "New Names and Combinations in the Genera Bacteroides Castellani and Chalmers, Fusobacterium Knorr, Eubacterium Prévot, Propionibacterium Orla-Jensen, and Lactobacillus Beijerinck."

\section{Comparative Immunology of Ribosomes and Disc Gel Electrophoresis of Ribosomal Proteins from Erwiniae, Pectobacteria, and Other Members of the Family Enterobacteriaceae}

NORMAN W. SCHAAD

University of Georgia, College of Agriculture Experiment Stations, Georgia Station, Experiment, Georgia 30212

Volume 24, no. 1, p. 44, column 1, lines 9 and 10: Change "Spinco 30 rotor for $2 \mathrm{~h}$ " to read "Spinco 30 rotor for $4 \mathrm{~h}$." Line 15: Change "Spinco 40 rotor for $4 \mathrm{~h}$ " to read "Spinco 40 rotor for $2 \mathrm{~h} . "$ 